\title{
Evaluation in pure and crossbreeding of the Large-White hyperprolific line in multiplier and commercial herds
}

\author{
G. PETIT (1), J.P. RUNAVOT (1), J. GRUAND ${ }^{(2)}$, C. LEGAULT ${ }^{(3)}$
}

(1) Institut Technique du Porc, Pôle Amélioration de l'Animal, B.P. 3, 35650 Le Rheu

(2) Institut National de la Recherche Agronomique, Station Expérimentale de Sélection Porcine, 86480 Rouille

(3) Institut National de la Recherche Agronomique, Station de Génétique quantitative et appliquée, 78350 Jouy-en-Josas

In 49 multiplier and commercial herds, reproductive performance of 92 purebred Large-White and 169 Large-White $\times$ Landrace crossbred females sired by 8 Large-White hyperprolific $(\mathrm{H})$ boars was compared with that of contemporary females from the same genetic types (126 purebreds and 266 crossbreds), born in the same herd and reared in the same conditions.

Purebred and crossbred daughters of $\mathrm{H}$ boars showed a definite advantage in prolificacy +0.96 and +0.61 in total number of piglets at birth, +0.87 and +0.52 in number of piglets born alive. As no systematic recording system had been implemented regarding transfer of piglets between litters, information on litter size at weaning is not fully reliable. No significant difference is observed for age at first farrowing, interval between farrowings and interval from weaning to fertile mating.

The comparison of the two types of progeny for traits recorded in the " on-the-farm " programme (age and backfat thickness at $100 \mathrm{~kg}$ liveweight) shows a slight genetic delay of the $\mathrm{H}$ line in production traits. The overall economic interest of using the $\mathrm{H}$ line is discussed.

\section{Relationships between genetic markers and production traits in pigs}

\author{
Christine RENARD ${ }^{(1)}$, J.P. BIDANEL ${ }^{(2)}$, G. PETIT ${ }^{(3)}$, Agnès PALOVICS ${ }^{(4)}$, \\ M. VAIMAN ${ }^{(5)}$, G. GUERIN ${ }^{(4)}$, J.P. RUNAVOT ${ }^{(3)}$ \\ (1) Institut National de la Recherche Agronomique, L.R.A., 78350 Jouy-en-Josas \\ (2) Institut National de la Recherche Agronomique, Station de Génétique quantitative \\ et appliquée, 78350 Jouy-en-Josas \\ (3) Institut Technique du Porc, Région Ouest, B.P., 35650 Le Rheu \\ (4) Institut National de la Recherche Agronomique, Laboratoire de Génétique Biochimique, \\ 78350 Jouy-en-Josas \\ (5) Centre d'Etudes Atomiques, I.P.S.N.-D.P.S.-S.P.E.-L.R.A., \\ 91191 Gif-sur-Yvette Cedex
}

A total of 243 female pigs were tested for 9 different genetic polymorphisms, and the results were related to production traits. The genetic systems studied were the blood groups A, E and $\mathrm{H}$, the proteins Phi, Po2, Pgd, Pil and Tf, and the class I lymphocyte antigens of the swine major histocompatibility complex (SLA). The production traits were growth rate, carcass quality (muscle/ fat ratio) and meat quality (as measured by $\mathrm{pH}$, water holding capacity and reflectance). The animals were from the Large-White (LW) and French Landrace (LF) breeds, which differed in allelic frequencies at most loci. Among the genetic systems studied, only SLA showed a marked association with production traits. Although there was no association with growth rate, in either breed, certain SLA haplotypes were associated with meat quality (reflectance) in the LW. In both breeds, there was a close association between SLA and carcass leanness, although the same haplotype was surprisingly associated with a lower fat content in the LW and with a higher fat content in the LF. This finding indicates that caution is required in the interpretation of such studies, without a fuller understanding of the metabolic processes concerned. 